\title{
Identifying and investigating pesticide application types to promote a more sustainable pesticide use: the case of smallholders in Boyacá, Colombia
}

Article

Accepted Version

Feola, G. and Binder, C. R. (2010) Identifying and investigating pesticide application types to promote a more sustainable pesticide use: the case of smallholders in Boyacá, Colombia. Crop Protection, 29 (6). pp. 612-622. ISSN 0261-2194 doi: https://doi.org/10.1016/j.cropro.2010.01.008 Available at https://centaur.reading.ac.uk/23996/

It is advisable to refer to the publisher's version if you intend to cite from the work. See Guidance on citing.

Published version at: http://www.sciencedirect.com/science/article/B6T5T-4YPGHST-

1/2/2af48d0cfedb0c43a03d319941072445

To link to this article DOI: http://dx.doi.org/10.1016/j.cropro.2010.01.008

Publisher: Elsevier

All outputs in CentAUR are protected by Intellectual Property Rights law, including copyright law. Copyright and IPR is retained by the creators or other copyright holders. Terms and conditions for use of this material are defined in the End User Agreement. 


\section{CentAUR}

Central Archive at the University of Reading

Reading's research outputs online 
Identifying and investigating pesticide application types to promote a more sustainable pesticide use. The case of smallholders in Boyacá, Colombia.

Giuseppe Feola ${ }^{1 *}$, Claudia R. Binder ${ }^{1,2}$

1 Unit for Social and Industrial Ecology, Department of Geography, University of Zurich, Winterthurerstrasse 190, 8057 Zurich, Switzerland

2 Institute for System Sciences, Innovation and Sustainability Research, University of Graz, Austria, Merangasse 18/I, 8010 Graz, Austria

* Corresponding author: email: giuseppe.feola@geo.uzh.ch;

\section{Suggested citation:}

Feola G., Binder C.R. 2010. Identifying and investigating pesticide application types to promote a more sustainable pesticide use. The case of smallholders in Boyacá, Colombia. Crop Protection, 29:612-622. 


\begin{abstract}
The present paper investigates pesticide application types adopted by smallholder potato producers in the Department of Boyacá, Colombia. In this region, environmental, health and adverse economic effects due to pesticide mis- or over-use respectively have been observed. Firstly, pesticide application types were identified based on input-effectiveness. Secondly, their determinants of adoption were investigated. Finally suggestions were given to develop intervention options for transition towards a more sustainable pesticide use. Three application types were identified for fungicide and insecticide. The types differed in terms of input (intensity of pesticide application), effect (damage control), frequency of application, average quantity applied per application, chemical class, and productivity. Then, the determinants of different pesticide application types were investigated with a multinomial logistic regression approach and applying the integrative agent centred (IAC) framework. The area of the plot, attendance at training sessions and educational and income levels were among the most relevant determinants. The analysis suggested that better pesticide use could be fostered to reduce pesticide-related risks in the region. Intervention options were outlined, which may help in targeting this issue. They aim not only at educating farmers, but to change their social and institutional context, by involving other agents of the agricultural system (i.e. pesticide producers), facilitating new institutional settings (i.e. cooperatives) and targeting social dynamics (i.e. conformity to social norms).
\end{abstract}

\title{
Key words
}

Pesticide use, application type, input-effectiveness, integrative agent-centred framework, Colombia 


\section{Introduction}

Potato is the crop with the highest demand for fungicides and insecticides in Colombia (Ministerio de Agricultura y Desarrollo Rural, 2006). The cultivation of potato is mainly concentrated in the Andean regions of Boyacá, Cundinamarca and Nariño and carried out by smallholders (Ministerio de Agricultura y Desarrollo Rural, 2006). Similarly to that which happens in many rural areas in developing countries (DC) (Matthews, 2008), smallholders usually apply pesticide by means of a lever-operated knapsack sprayer and often wear insufficient or inappropriate personal protective equipment (Feola and Binder, 2010). In addition, smallholder potato producers in these regions often tend to over- or mis-use pesticides (Gobernación de Boyacá Direccion de Desarrollo Agropecuario, 2004; Ministerio de Agricultura y Desarrollo Rural, 2006).

Misuse of personal protective equipment and pesticide over- and mis-use are commonly related to high exposure to pesticide and consequently to adverse health and environmental effects, especially in DC (WHO, 1990; Ecobichon, 2001; Wilson and Tisdell, 2001). In effect, different studies suggested that farmers in the region of Boyacá and their environment may be at risk because of exposure to pesticide (Fedepapa and Ministerio de Ambiente, Vivienda y Desarrollo Territorial, 2004; Tuchschmid, 2004; Leuenberger, 2005; Baumberger, 2008; Ospina et al., 2008).

Furthermore, pesticide overuse has attracted the concern of governmental agencies because of its negative economic consequences (Ministerio de Agricultura y Desarrollo Rural, 2004). While increasing productivity rates is considered essential, crop protection products represent around $14 \%$ of the production costs for smallholders (Ministerio de Agricultura y Desarrollo Rural, 2001; Gobernación de Boyacá Dirección de Desarrollo Agropecuario, 2004), which, as noted by Ashburner and Friederich (2001) and Blackie and Gibbon (2003), is considered to be a sign of problematic pest control tactics. Therefore, in a context where access to credit is very limited (Ministerio de Agricultura y Desarrollo Rural, 2006), more efficient pesticide use may not only reduce environmental and health risks, but also constitute a better economic strategy for smallholders.

The present paper addresses pesticide application types defined in terms of chemical class, intensity, and frequency of application, and their input-effectiveness, i.e. the ratio between effectiveness (pest damage control) and input (pesticide application intensity). The above mentioned studies suggest that there is the need for smallholders in Boyacá to increase their pesticide use input-effectiveness. This would reduce environmental and health risks, as well as the burden of production costs on households' livelihoods. Thus, while previous studies in the region have raised the issue of pesticide over- and mis-use, the present paper goes further in identifying application types and their determinants of adoption, in order to suggest options for intervention to foster a transition towards a more inputeffective, and therefore sustainable pesticide use.

The success of any intervention aiming at more sustainable agricultural practices depends on an in-depth knowledge of farmers' behaviour (Öhlmer et al., 1998; Webster, 1999; McGregor et al., 2001; Edwards-Jones, 2006). This has been investigated from different perspectives. Some scholars have stressed that pesticide use is influenced by other productive factors, such as fertilizer use, or locked into other management choices such as application method or crop rotation (e.g. Rahman, 2003; Lin et al., 1995). Others have mainly considered farmers' socio-demographic characteristics, such as gender or education (e.g. Mekonnen and Agonafir, 2002; Atreya, 2007) or farmers' individuality and propensity to experiment (Grossman, 1992). Also, the need for increasing pesticide use due to growing pest resistance to pesticides has been pointed out as the cause of a lock-in effect for farmers who opt for the chemical control of pests (e.g. Wilson and Tisdell, 2001). Lock-in into unsustainable pesticide use may also be due to problems of coordination among farmers, lack of knowledge about the alternatives or uncertainty about the consequences of alternatives (Cowan and Gunby, 1996). Further, contextual conditions such as national policies or international trade channels can also influence farmers' pest management choices (Williamson et al., 2008). Finally, other studies have shown the importance of social factors, such as the personal norms (Heong and Escalada, 1999; Heong et al., 2002) or beliefs and risk perception (e.g. Lichtenberg and Zilberman, 1986; Heong et al., 2002). 
Although each of the above-mentioned strands of research contributes significantly to understand farmers' pesticide misuse, these analyses only tackle partial aspects and therefore can offer only a limited contribution to the development of interventions for the transition to more sustainable pesticide use. In fact, a whole body of literature has called for more integrative approaches to the study of farmers' behaviour and agricultural systems (e.g. Park and Seaton, 1996; Oriade and Dillon, 1997; Berger, 2001; Belcher et al., 2004; EdwardJones, 2006; Galt, 2008).

The integrative agent-centred (IAC) framework is a conceptual tool which responds to this need for integrative research on farmers' behaviour (Feola and Binder, 2009). It is based on: i) an explicit and well-motivated behavioural theory; ii) an integrative approach; iii) feedback processes, in particular between agents' behaviour and system's dynamics, which are all considered essential to understand farmers behaviour and support the governance of complex agricultural systems (Norgaard, 1984; Dent et al., 1995; Park and Seaton, 1996; Edward-Jones, 2006; Thompson et al., 2007).

The present paper adopts the IAC framework to understand pesticide use among smallholder potato growers in the Department of Boyacá, Colombia. It aims to: (i) analyse farmers' pesticide use and identify different application types; (ii) investigate the factors affecting farmers' adoption of a specific application type; iii) suggest intervention options for a transition to a more sustainable pesticide use.

\section{Method}

\subsection{Study area}

The study area consisted of four veredas (communities) located in the Department of Boyacá, on the eastern chain of the Colombian Andes (Figure 1). It is a rural region mainly devoted to the cultivation of potato (although carrots, maize, wheat, beans, and oats are other relevant crops) (Ministerio de Agricultura y Desarrollo Rural, 2006).

Figure 1. Study area (Oehler, 2008)

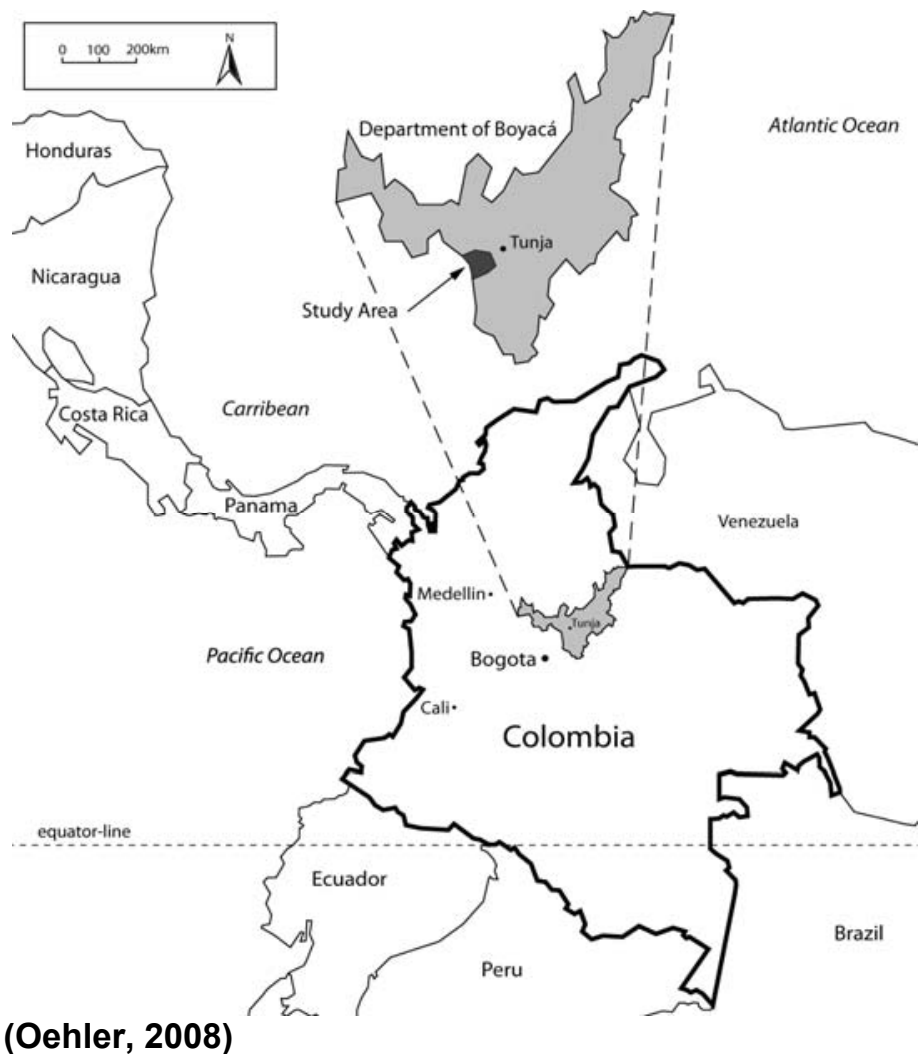

The production of potato in the Department of Boyacá relies mainly on smallholders, who make up more than the $95 \%$ of the workforce, occupy more than the $56 \%$ of the potato- 
cultivated land and provide $45 \%$ of the total production (Ministerio de Agricultura y Desarrollo Rural, 2006). Smallholders cultivate an average of 3 hectares, subdivided into different plots, which are often distant from each other and on terrains which are not appropriate for mechanization, thus leading to low average production rates. Due to a lack of irrigation devices, smallholders are significantly dependent on the rain cycles for production. Therefore, the production of potato is generally organized in two cycles, i.e. MarchSeptember and October-February, corresponding to the two rainy seasons (Gobernación de Boyacá Direccion de Desarrollo Agropecuario, 2004). The texture of soil in the study area is mostly sandy loam or sandy clay loam (Binder and Patzel, 2001). Average productivity rates range between 15 and 17 tonnes per hectare (Ministerio de Agricultura y Desarrollo Rural, 2006).

More than 10 varieties of potato are cultivated in the study area; Ica Húila (also called Diacol Capiro), Pastusa, Ica Única and Tuquerreña are the four most relevant ones. Potato crops in this region are vulnerable to three major pests: the soil-dwelling larvae of the Andean weevil (Premnotrypes vorax), the late blight fungus (Phytophthora infestans) and the Guatemalan potato moth (Tecia solanivora).

The most common way of applying the chemicals is by means of a lever-operated knapsack sprayer (20-25 liters), which is filled from a bigger tank (caneca), usually of about 200 litres, where the pesticide mix (batida) is prepared. The same sprayer is used either to inject pesticides in the soil or, more often, to spray them on the crop.

Fungicides and insecticides are widely applied, while herbicides are only used by a small number of farmers in the four communities. About 20 different formulations of fungicides and 30 insecticides are applied, which correspond to 12 and 17 active ingredient compositions, respectively (Table 1). 
Table 1. Pesticide used in the study area (own survey, 2007).

\begin{tabular}{|c|c|c|}
\hline \multicolumn{3}{|c|}{ FUNGICIDES } \\
\hline Active ingredient(s) & Commercial name(s) & Toxicity class \\
\hline Carboxil & Vitavax 300 & II \\
\hline Chlorothalonil & Daconil 720 SC; Ridonate 720 SC & la \\
\hline Copper Oxachloride & Oxicloruro de cobre $58.8 \%$ WP & II \\
\hline Dimethomorph & Forum 500 WP & II \\
\hline Fentine Hydroxide & $\begin{array}{l}\text { Brestanid } 500 \text { SC; Duter } 20 \% \\
\text { Cobrethane; Dithane M- } 45 \text { WP NT; Manzate; }\end{array}$ & II \\
\hline Mancozeb & Manzate 200 WG; Manzate 200 WP & II \\
\hline Mancozeb; Cymoxanil & Curathane; Curzate M-8; Cymozeb & II \\
\hline Mancozeb; Metalaxil & Ridomil Gold MZ 68 WP & II \\
\hline Mancozeb; Oxadixil & Sandofan M & II \\
\hline Prochloraz & Mirage $45 \mathrm{EC}$ & II \\
\hline $\begin{array}{l}\text { Propamocarb; } \\
\text { Hydrochloride }\end{array}$ & Previcur N SL & III \\
\hline Propineb & Antracol WP 70 & II \\
\hline Propineb; Cymoxanil & Fitoraz WP 76 & II \\
\hline \multicolumn{3}{|c|}{ INSECTICIDES } \\
\hline Active ingredient(s) & Commercial name(s) & Toxicity class \\
\hline Acephate & Orthene $75 \%$ SP & II \\
\hline Alfa Cypermethrin & $\begin{array}{l}\text { Dominex } 10 \text { EC } \\
\text { Carbofuran } 3 \text { GR Coljap; Carbofuran } 330 \text { SC } \\
\text { Coljap; Carboter; Curater; Furadan } 3 \text { GR; }\end{array}$ & II \\
\hline Carbofuran & Furadan 3 SC; Fursem; & la \\
\hline Carbosulfan & Eltra $48 \mathrm{EC}$ & la \\
\hline Chlorpyrifos & Pyrinex 4 EC; Lorsban 4 EC; Niferex 48 EC & II \\
\hline $\begin{array}{l}\text { Chlorpyrifos; } \\
\text { Cypermethrin }\end{array}$ & Latigo EC & $\mathrm{lb}$ \\
\hline Cypermethrin & Cipermetrina 200 EC & $\mathrm{lb}$ \\
\hline Deltamethrin & $\begin{array}{l}\text { Decis } 2.5 \mathrm{EC} \\
\text { Agrometox } 40 \mathrm{EC} \text {; Roxion } 40 \mathrm{EC} \text {; Sistemin } 40\end{array}$ & II \\
\hline Dimethoate & EC & $\mathrm{lb}$ \\
\hline Lambda Cyhalothrin & Karate Zeon SC & II \\
\hline Malathion & $\begin{array}{l}\text { Malathion 57\% EC } \\
\text { Tamaron SL 600; Monitor; Nadir } 600 \text { SL; }\end{array}$ & la \\
\hline Methamidophos & Metamidofos 600 Proficol; & la \\
\hline Methomyl & Methavin 90 SP; Lannate 40 SP; Lannate -SL & $\mathrm{lb}$ \\
\hline Permethrin & Pirestar $38 \mathrm{EC}$ & II \\
\hline Profenofos & Curacron 500 EC & $\mathrm{lb}$ \\
\hline $\begin{array}{l}\text { Thiamethoxam; } \\
\text { Lambda Cyhalothrin }\end{array}$ & Engeo & II \\
\hline Thiodicarb & Larvin 375 SC & II \\
\hline
\end{tabular}

\subsection{Data}

The data describing the four veredas were collected through a survey conducted in September-October 2007. The integrative agent-centred (IAC) framework (Feola and Binder, 2009) was used as a basis for designing the structured questionnaire. The questionnaire was structured in sections, each one corresponding to a class of behavioural drivers and containing one or more questions for each variable. The questions referred to the timeframe of one cultivation cycle and to a pre-selected reference parcel. In the survey a total of 197 smallholder potato growers, $88.3 \%$ of whom were males, were involved in the four communities: a main study area (Vereda La Hoya, Province of Tunja, 81 farmers), and three comparative ones (Puente Boyacá, Province of Ventaquemada, 47; Hato de Ventaquemada, 
Province of Ventaquemada, 23; San Francisco, Province of Toca, 46). In Vereda La Hoya the sample covered the whole population of potato growers (with the exception of those refusing and of farmers not available at the time of the survey, which in total corresponded to $36 \%$ of the 127 total households). In the comparative areas, the farmers were sampled according to the snowball method because a reliable list of the population was not available and because this method allowed more trusting relationships with the farmers to be built. Therefore, the sample was statistically not representative. At the time of the survey, 96 farmers had already harvested the crop for that agricultural cycle, 42 of those in La Hoya, 19 in San Francisco, 28 in Puente Boyacá and 7 in Hato de Ventaquemada.

Local professional interviewers (Sistemas Especializados de Información, SEI s.a.) contributed to the translation of the questionnaire and carried out the interviews. The pre-test took place in August 2007 on 17 farmers in a neighbouring and comparable area (Vereda Guantoque, Province of Samacá). The survey was then conducted in September-October 2007.

Several measures were taken to minimize the potential systematic error for the questions in which the respondent was asked to recall the amount and name of pesticide used in the past. Firstly, questions were posed with reference to a selected potato parcel, namely the one the farmer reported to know best. Secondly, questions referred only to the last season (approximately the last six months preceding the interview), to make the timeframe precise and as close as possible to the time the interview took place. Thirdly, the agricultural season was divided into five sub-phases (from sowing to harvesting), to make the questions coherent with the kind of reasoning of farmers in the region, who tend to organize their work in the field according to such phases, and to help the respondent recall the information. Fourthly, interviewers were instructed to ask, whenever possible, for the packages of pesticide mentioned by the respondent, to help the farmer recall the information and to partly verify the validity of the answer. Finally, data were collected by means of handheld electronic devices for data capture, which were purposively programmed for a real-time crosscheck for inconsistencies. Data were analysed with SPSS 14.0.

\subsection{Theoretical background and models specification}

Fungicide and insecticide application types were identified based on the value of the inputeffect index and characterized by: i) intensity; ii) frequency of application; iii) chemical class. The typology was built in a three step procedure. Firstly, production functions were estimated using three damage control function specifications. Secondly, fungicide and insecticide application types were identified by calculating the input-effect index, which is a ratio between the estimated value of the damage control function and the pesticide application intensity. This was done for each farmer and separately for fungicides and insecticides. Thirdly, the determinants of adoption of a pesticide application type were investigated by means of a multinomial logistic regression approach based on the integrative agent-centred framework.

\subsubsection{Production functions}

Following Lichtenberg and Zilberman (1986), Babcock et al. (1992) and Carrasco-Tauber and Moffit (1992), three production function specifications, i.e. exponential, logistic and Weibull, were estimated along with the conventional Cobb-Douglas formula. These three functional specifications account for the specificity of damage control agents, such as fungicides and insecticides, which, in contrast to other inputs, do not enhance productivity directly.

While in the conventional Cobb-Douglas production function the production $Q$ is defined as a function of inputs $Z$ (directly productive) and $X$ (damage control agents): $Q=F[Z, X]$, in the alternative specifications the production $Q$ is defined as a function of directly productive inputs $Z$ and of a damage control, or damage abatement, function $G(X): Q=F[Z, G(X)]$. The damage control function $G(X)$ is defined as "the proportion of the destructive capacity of the damaging agent eliminated by the application of a level of control agent X" (Lichtenberg and Zilberman, 1986) and ranges between 0 and 1 , with $G(X)=1$ and $G(X)=0$ denoting complete and null abatement of the pests' destructive capacity, respectively. The damage 
control function increases with the increasing use of the damage control agent, with a distribution that can take three forms (Lichtenberg and Zilberman, 1986):

- Exponential: $1-\exp (-\lambda X)$

- Logistic: $[1+\exp (\mu-\sigma X)]^{-1}$

- Weibull: $1-\exp \left(X^{c}\right)$

where: $X=$ damage control agent; $\lambda, \mu, \sigma, c=$ parameters for the different functional specifications.

Because there is no theoretical basis for preferring one form of the damage control function to the others (Carrasco-Tauber and Moffit, 1992), all three were used. Parameters were estimated based on the Levenberg-Marquardt estimation algorithm according to the following model specifications:

- Cobb-Douglas:

- Exponential:

- Logistic:

- Weibull:

$$
\begin{aligned}
& \ln Y=\ln A+\beta_{i} \ln Z_{i}+\ln X_{j} \\
& \ln Y=\ln A+\beta_{i} \mid \ln Z_{i}+\ln \left[1-\exp \left(-\lambda X_{j}\right)\right] \\
& \ln Y=\ln A+\beta_{i} \ln Z_{i}+\ln \left[1+\exp \left(\mu-\sigma X_{j}\right)\right]^{-1} \\
& \ln Y=\ln A+\beta_{i} \ln Z_{i}+\ln \left[1-\exp \left(-X_{j}^{C}\right)\right]
\end{aligned}
$$

where: $Y$ is the output; $A$ is the constant value; $Z_{i}$ are the production inputs, such as seed,

\begin{tabular}{|c|c|c|c|}
\hline Variable & Description $^{1}$ & $\begin{array}{c}\text { Mean / \% } \\
\text { meeting } \\
\text { condition } \\
\text { (value=1) } \\
\text { for } \\
\text { dummy } \\
\text { variables }\end{array}$ & SD \\
\hline PROD_POTATO & Yield in $\mathrm{kg}$ per hectare & 12647.15 & 9148.27 \\
\hline FERTIL & Quantity $(\mathrm{kg})$ of fertilizers applied per hectare in one cycle & 1981.19 & 1745.07 \\
\hline SEED_QUANT & Quantity $(\mathrm{kg})$ of seeds per hectare & 1005.96 & 606.41 \\
\hline SEED_TYPE & Dummy variable. Value 1 if the seeds used were certified. & 0.07 & 0.26 \\
\hline VARIETY & Dummy variable. Value 1 if the variety is Ica Húila. & 0.54 & 0.5 \\
\hline AREA & Parcel area (ha) & 1.02 & 0.73 \\
\hline DEPTH & $\begin{array}{l}\text { Dummy variable. Value } 1 \text { is the depth of the fertile soil is } \\
\text { more than } 30 \mathrm{~cm} \text {. }\end{array}$ & 0.65 & 0.48 \\
\hline SLOPE & $\begin{array}{l}\text { Dummy variable. Value } 1 \text { if the parcel is on a plain area } \\
(<8 \%) \text {. }\end{array}$ & 0.24 & 0.43 \\
\hline IRRIGATION & $\begin{array}{l}\text { Dummy variable. Value } 1 \text { if the parcel was irrigated. } \\
\text { Dummy variable. Value } 1 \text { if the parcel is in the area of } L a\end{array}$ & 0.14 & 0.34 \\
\hline LAHOYA & Hoya. & 0.44 & 0.5 \\
\hline EDUCATION & Years of farmer's formal education & 4.29 & 2.3 \\
\hline AGE & Farmer's age (years) & 47.29 & 14.64 \\
\hline TRAINING & $\begin{array}{l}\text { Dummy variable. Value } 1 \text { if the farmer received training from } \\
\text { governmental agencies or NGOs in the reference period. }\end{array}$ & 0.17 & 0.38 \\
\hline FUNGICIDE & $\begin{array}{l}\text { Quantity (kg) of active ingredients (fungicides) applied per } \\
\text { hectare in one cycle }\end{array}$ & 10.31 & 13.83 \\
\hline INSECTICIDE & $\begin{array}{l}\text { Quantity (kg) of active ingredients (insecticides) applied per } \\
\text { hectare in one cycle }\end{array}$ & 3.12 & 3.63 \\
\hline
\end{tabular}
fertilizer, and labour; $X_{i}$ are the damage control agents, i.e. fungicides or insecticides.

The variables considered in estimating the production function are shown in Table 2.

Table 2. Variables considered in the production function models.

\footnotetext{
${ }^{1}$ Where not specified, the dummy variables take the value zero when the condition (value $=1$ ) is not met.
} 


\subsubsection{Pesticide application types}

Using the parameters estimated in the production function (equations 5-8), the value of the damage control function was calculated for each farmer and separately for fungicides and insecticides, based on the three specifications as reported in equations (1), (2) and (3). Thus, the value of the damage control function was estimated through an econometric approach and not measured in the field (as for example done by Burleigh et al., 1998), the latter approach not being feasible within the time and resource constraints of the present research. Finally, the input-effect index (I-E) was calculated, as:

$$
\mathrm{I}-E_{\mathrm{jn}}=g\left(x_{\mathrm{j}}\right)_{\mathrm{n}} / \mathrm{q}_{\mathrm{jn}}
$$

where: $g\left(x_{j}\right)_{n}=$ estimated value of the damage control function for fungicides or insecticides for the $\mathrm{n}^{\text {th }}$ farmer; $\mathrm{q}_{\mathrm{jn}}=$ quantity of active ingredients (fungicides or insecticides) applied during an agricultural cycle ( $\mathrm{kg}$ a.i./ha) by the $\mathrm{n}^{\text {th }}$ farmer; a.i. = active ingredients.

The I-E index is a measure of benefit (estimated damage control) per unit of input (fungicide or insecticide). It ranges from 0 to infinity and shows that farmers can attain the same level of damage control by applying different quantities of pesticide per hectare in an agricultural cycle (Figure 2). It takes into consideration the value of the damage control function $\left(g\left(x_{j}\right)_{n}\right)$ and a measure of intensity $\left(q_{j n}\right)$. The latter, i.e. the quantity of active ingredients applied per unit of area in a selected period of time, is a measure commonly used in the literature (e.g. Rahman, 2003; Galt, 2008) and was calculated based on the survey data.

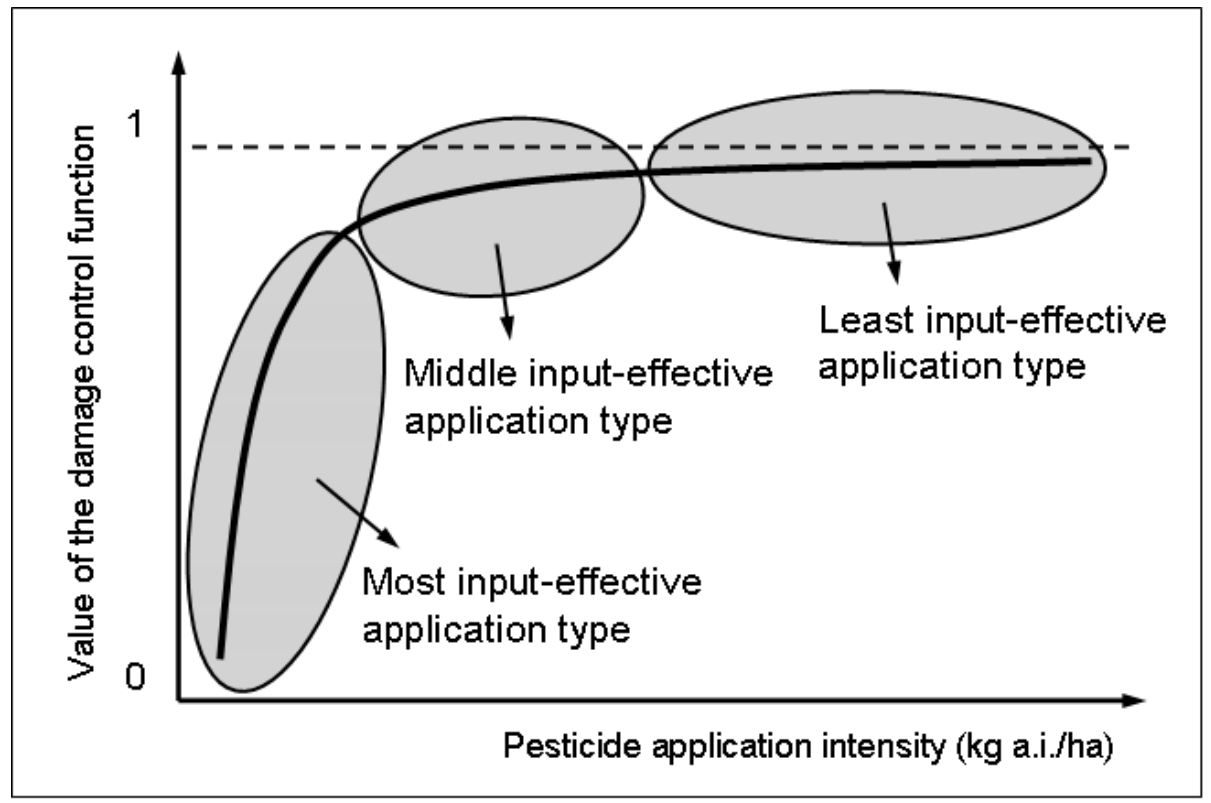

Figure 2. Graphical representation of the input-effect index.

Based on the I-E index, fungicide and insecticide application types were identified respectively. Thus, a low I-E index corresponds to a low input-effective application type, whereas, vice versa, a high I-E index corresponds to a highly input-effective application type (Figure 2).

\subsubsection{Determinants of adoption of different pesticide application types}

The determinants of adoption of different pesticide application types were investigated by adopting a multinomial logistic regression approach (Hosmer and Lemeshow, 2000). Accordingly, pesticide use was defined in terms of a nominal outcome: farmers were divided 
into three groups of equal size ${ }^{2}$, corresponding to different application types respectively and separately for fungicide and insecticide use. Because the damage control function was estimated for each farmer using three different functional specifications, three different values of the damage control function, and consequently of the I-E index, were attributed to each group.

The determinants of fungicide and insecticide use types were investigated separately, each with a full and a reduced model. Firstly, the full model was estimated for fungicide and insecticide use, respectively. The full models were then reduced through combined backward elimination and forward entry of the variables. Reducing the number of explanatory variables was necessary given the small sample available (valid cases: $n=93$ for insecticides; $n=80$ for fungicides), and allowed more reliable parameter estimates to be obtained, while still guaranteeing good explanatory power of the models. The reduced model was selected by maximizing the Akaike Information Criteria (Akaike, 1973), given a non-significant Pearson $\mathrm{Chi}^{2}$ test and a significant $\mathrm{Chi}^{2}$ test of the model.

The baseline category of the multinomial logistic regression models is the middle effective pesticide application type. The models were built by estimating the probability of a farmer adopting either the most effective or the least effective application type 1, instead of the middle effective one. The models are specified as follows:

$$
\ln \left[P_{g 2} / P_{g m}\right]=\beta_{0}+\beta_{1} X_{1}+\beta_{2} X_{2}+\ldots+\beta_{k} X_{k}
$$

where: $P$ is the probability of the outcome; $g=$ indicates the type, with $m=1$ or $3 ; \beta_{0}$ is the intercept term; $\beta_{1}, \beta_{2}, \ldots \beta_{k}$ are the coefficients associated with each explanatory variable; $X_{1}$, $X_{2}, \ldots X_{k}$ are the explanatory variables; the subscript $k$ denotes the $k^{\text {th }}$ variable in the model.

The explanatory variables were selected based on the integrative agent-centred (IAC) framework (Feola and Binder, 2009), which allows for combining different behavioural drivers and, therefore, for depicting a complex and potentially varied model of human behaviour. In addition, it integrates an individual and a systemic perspective, thus providing a basis for investigating on the one hand, the contribution of individual action to the dynamics of a local agricultural Social-Ecological System and, on the other, the influences of the system on farmers' behaviour.

In the IAC framework, the decision of an agent to enact a specific behaviour is influenced by external and internal drivers. The external drivers consist of contextual factors (i.e. facilitating conditions or barriers) whereas the internal ones include habit (the frequency of past behaviour), physiological arousal (the physiological state of the individual) and intention. The latter is determined by: i) expectations (beliefs about the outcomes, their probability and their value); ii) subjective culture (social norms, roles and values); iii) affect (the feelings associated with the act). The agent's actions have consequences that give rise to a double feedback loop, i.e. towards internal and external behavioural drivers, and thus influence decisions in the future (Figure 3 ).

\footnotetext{
${ }^{2}$ A cluster analysis was done. However, even with different methods, the small size of the groups formed would have hindered further analysis.
} 


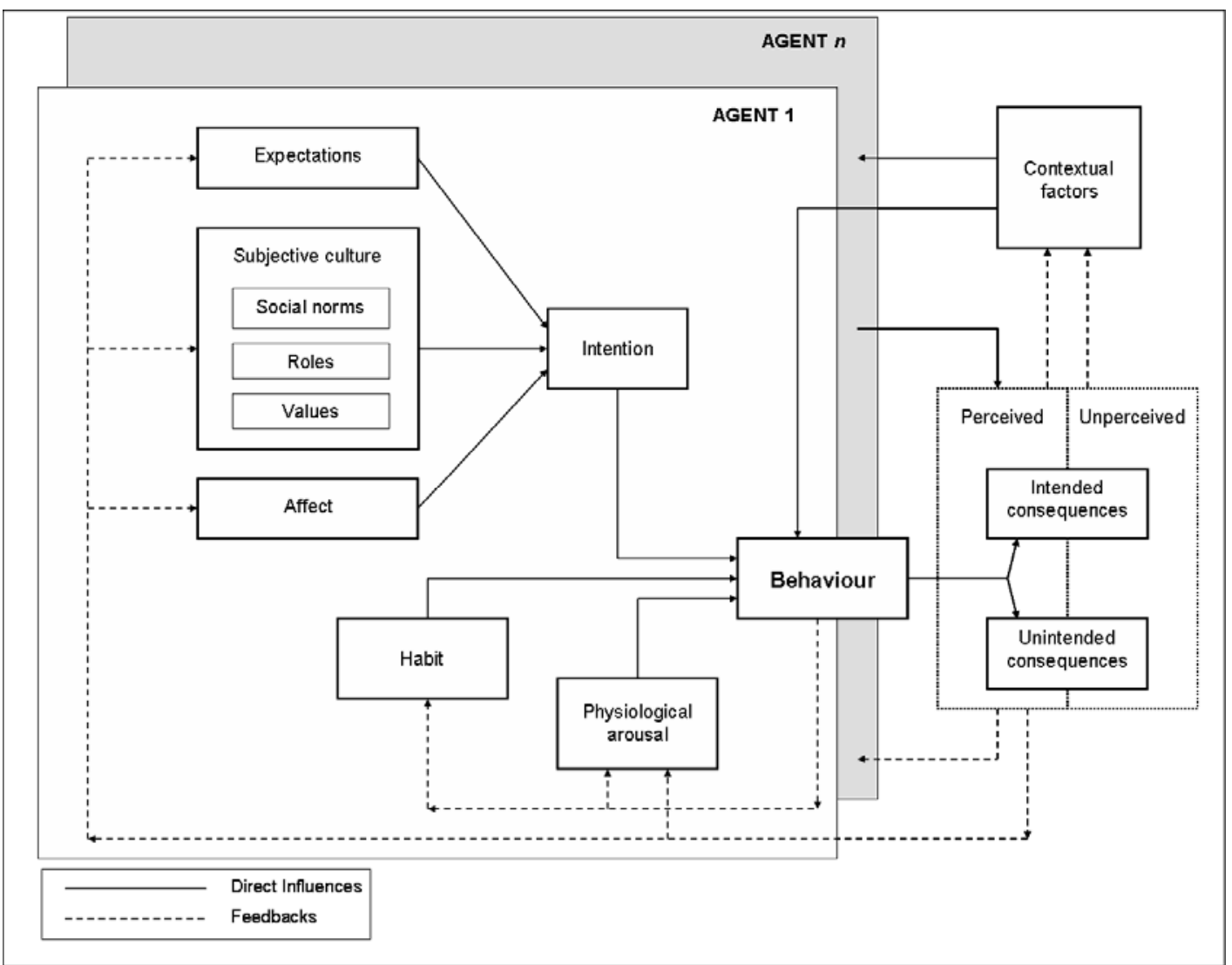

Figure 3. The IAC framework (after Feola and Binder, 2009)

The components of the framework considered in the present study and the explanatory variables accordingly included in the multinomial logistic regression models are shown in Table 3. 


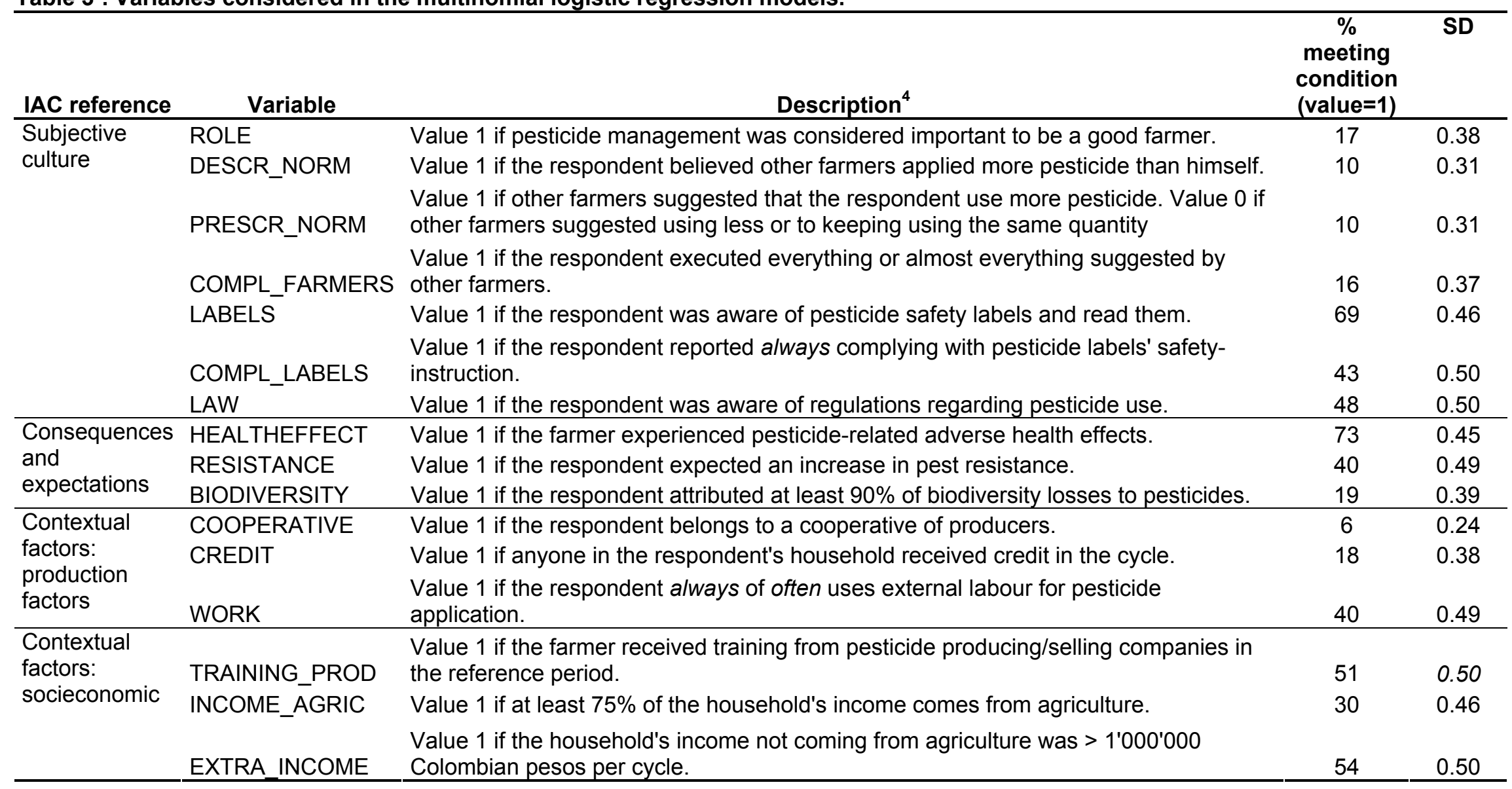

\footnotetext{
${ }^{3}$ Not included in this Table, because already included in Table 1, the description of the following variables: LA_HOYA; AGE; EDUCATION; TRAINING; AREA;
} VARIETY; SEED_TYPE.

${ }^{4}$ All variables are dummy variables. Where not specified, the variables take the value zero when the condition (value=1) is not met. 


\section{Results}

\subsection{Production functions}

The estimates of the production function models are shown in Table 4. All models had good explanatory power $\left(R^{2}\right.$ between 0.546 and 0.629$)$ and converged on the sign and significance of the independent variables. The production function models with damage control specification had a higher explanatory power than the Cobb-Douglas one (Table 4), which confirms the advantage of adopting such specifications. All the signs were as expected, except for TRAINING, which was negative, surprisingly suggesting a negative influence of training programmes on farmers' productivity.

The estimates indicate that the quantity of fertilizers (FERTIL) and of seeds used per hectare (SEED_QUANT), as well as a fertile soil deeper than 30 centimetres (DEPTH) and the years of formal education of the farmer (EDUCATION), had a significant positive impact on production. INSECTICIDES and FUNGICIDES showed a positive sign in all the models, but were both significant only in the model based on the exponential functional specification of the damage control function.

In addition, although not significant, SEED_TYPE, VARIETY, AREA, IRRIGATION and AGE were also positively related to the dependent variable. That is, certified seeds, variety Ica Huila, bigger parcels, availability and use of irrigation equipment and age all positively contributed to productivity. Finally, as hypothesized based on anecdotal evidence, farmers in La Hoya (LAHOYA) were less productive than those in the comparative communities. 
Table 4. Estimates of the production function.

\begin{tabular}{|c|c|c|c|c|}
\hline \multirow[b]{2}{*}{ Variables } & \multirow[t]{2}{*}{ Cobb-Douglas } & \multicolumn{3}{|c|}{ Damage control specification } \\
\hline & & Exponential & Logistic & Weibull \\
\hline Constant & $\begin{array}{c}1.378 \\
(0.908)\end{array}$ & $\begin{array}{c}1.979 \\
(1.443)\end{array}$ & $\begin{array}{c}-174.846 \\
(-0.003)\end{array}$ & $\begin{array}{c}2.542 \\
(1.865)\end{array}$ \\
\hline FERTIL & $\begin{array}{c}0.312 \\
(2.088) \text { ** }\end{array}$ & $\begin{array}{c}0.322 \\
(2.348) \text { ** }\end{array}$ & $\begin{array}{c}0.312 \\
(2.053) \text { ** }\end{array}$ & $\begin{array}{c}0.311 \\
(2.307)^{* *}\end{array}$ \\
\hline SEED_QUANT & $\begin{array}{c}0.488 \\
(2.515) \text { ** }\end{array}$ & $\begin{array}{c}0.494 \\
(2.783)^{* * *}\end{array}$ & $\begin{array}{c}0.488 \\
(2.473) \text { ** }\end{array}$ & $\begin{array}{c}0.501 \\
(2.872)^{* * *}\end{array}$ \\
\hline SEED_TYPE & $\begin{array}{c}0.177 \\
(0.495)\end{array}$ & $\begin{array}{c}0.043 \\
(0.131)\end{array}$ & $\begin{array}{c}0.177 \\
(0.486)\end{array}$ & $\begin{array}{c}0.155 \\
(0.479)\end{array}$ \\
\hline VARIETY & $\begin{array}{c}0.195 \\
(1.139)\end{array}$ & $\begin{array}{c}0.229 \\
(1.476)\end{array}$ & $\begin{array}{c}0.195 \\
(1.120)\end{array}$ & $\begin{array}{c}0.204 \\
(1.325)\end{array}$ \\
\hline AREA & $\begin{array}{c}0.168 \\
(1.304)\end{array}$ & $\begin{array}{c}0.089 \\
(0.792)\end{array}$ & $\begin{array}{c}0.168 \\
(1.276)\end{array}$ & $\begin{array}{c}0.125 \\
(1.119)\end{array}$ \\
\hline DEPTH & $\begin{array}{c}0.459 \\
(2.599)^{* *}\end{array}$ & $\begin{array}{c}-0.485 \\
(-3.014)^{* * *}\end{array}$ & $\begin{array}{c}-0.459 \\
(-2.551)^{* *}\end{array}$ & $\begin{array}{c}0.456 \\
(2.859)^{* * *}\end{array}$ \\
\hline SLOPE & $\begin{array}{c}-0.030 \\
(-0.175)\end{array}$ & $\begin{array}{c}0.031 \\
(0.193)\end{array}$ & $\begin{array}{l}-0.031 \\
(0.172)\end{array}$ & $\begin{array}{c}-0.030 \\
(-0.193)\end{array}$ \\
\hline IRRIGATION & $\begin{array}{c}0.294 \\
(1.279)\end{array}$ & $\begin{array}{c}0.370 \\
(1.816) \text { * }\end{array}$ & $\begin{array}{c}0.294 \\
(1.213)\end{array}$ & $\begin{array}{c}0.254 \\
(1.242)\end{array}$ \\
\hline LAHOYA & $\begin{array}{c}-0.084 \\
(-0.473)\end{array}$ & $\begin{array}{c}-0.060 \\
(-0.367)\end{array}$ & $\begin{array}{l}-0.085 \\
(-0.464)\end{array}$ & $\begin{array}{l}-0.072 \\
(-0.444)\end{array}$ \\
\hline EDUCATION & $\begin{array}{c}0.404 \\
(2.617)^{* *}\end{array}$ & $\begin{array}{c}0.380 \\
(2.708)^{* * *}\end{array}$ & $\begin{array}{c}0.404 \\
(2.571) \text { ** }\end{array}$ & $\begin{array}{c}0.370 \\
(2.691)^{* * *}\end{array}$ \\
\hline AGE & $\begin{array}{c}0.219 \\
(0.863)\end{array}$ & $\begin{array}{c}0.191 \\
(0.829)\end{array}$ & $\begin{array}{c}0.219 \\
(0.848)\end{array}$ & $\begin{array}{c}0.164 \\
(0.724)\end{array}$ \\
\hline TRAINING & $\begin{array}{c}-0.322 \\
(-1.376)\end{array}$ & $\begin{array}{c}-0.248 \\
(-1.162)\end{array}$ & $\begin{array}{c}-0.322 \\
(-1.343)\end{array}$ & $\begin{array}{c}-0.265 \\
(-1.261)\end{array}$ \\
\hline FUNGICIDE & $\begin{array}{c}0.217 \\
(3.275)^{* * *}\end{array}$ & & & \\
\hline INSECTICIDE & $\begin{array}{c}0.089 \\
(1.154)\end{array}$ & & & \\
\hline$\lambda$ FUNGICIDE & & $\begin{array}{c}0.660 \\
(3.591)^{* * *}\end{array}$ & & \\
\hline$\lambda$ INSECTICIDE & & $\begin{array}{c}5.276 \\
(2.277)^{* *}\end{array}$ & & \\
\hline$\mu$ FUNGICIDE & & & $\begin{array}{c}-4.603 \\
(-0.023)\end{array}$ & \\
\hline$\sigma$ FUNGICIDE & & & $\begin{array}{c}0.002 \\
(0.004)\end{array}$ & \\
\hline$\mu$ INSECTICIDE & & & $\begin{array}{c}-4.324 \\
(-0.005)\end{array}$ & \\
\hline б INSECTICIDE & & & $\begin{array}{c}0.001 \\
(0.001)\end{array}$ & \\
\hline c FUNGICIDE & & & & $\begin{array}{c}0.459 \\
(1.367)\end{array}$ \\
\hline c INSECTICIDE & & & & $\begin{array}{c}0.230 \\
(1.695) \text { * }\end{array}$ \\
\hline $\mathrm{R}^{2}$ & 0.546 & 0.612 & 0.629 & 0.620 \\
\hline
\end{tabular}

Significance: ${ }^{* *} 1 \%,{ }^{* *} 5 \%,{ }^{*} 10 \% . T$ statistic in brackets.

\subsection{Pesticide application types}

The different application types are summarized in Tables 5-8. Because all the functional specifications considered (i.e. exponential, logistic and Weibull) allocate farmers to the same 
three application types respectively, only the values of the input-effect index calculated using the exponential specification are presented in this section.

\subsubsection{Fungicide application types}

Three types of fungicide application were identified, i.e. least, middle and most inputeffective (Table 5). The types showed significant differences with respect to the input-effect index, the intensity and the number of applications and the damage control achieved. Significant differences were also observed for the average quantity of active ingredients applied per application. Hence, the three fungicide application types differed by: i) increasing intensity of application, i.e. total amount of active ingredients applied per hectare; ii) number of applications; iii) amount of active ingredients applied per application per hectare. An increasing effect (damage control) corresponded to the increasing intensity, although the effect was achieved with lower value of the input-effect ratio. For example, farmers who adopted the least input-effective application type applied an amount of active ingredients (fungicide) which was more than proportional than the increased benefit they achieved, in comparison with farmers who adopted the middle input-effective type.

The three types only slightly differed with respect to the chemical class of fungicide applied (Table 5). In effect, the types corresponded to an increase in the use of carbamates over other chemical classes, with the least input-effective application type characterised by the highest and the most input-effective one by the lowest share of carbamates over the total amount of fungicide applied.

\subsubsection{Insecticide application types}

Three types of insecticide application were identified, i.e. least, middle and most inputeffective (Table 6). The types show significant differences with respect to the input-effect index, the intensity of application and the damage control achieved. Significant differences were also observed for the average quantity of active ingredients applied per application. A significant difference in terms of number of applications was observed only between the middle and the least input-effective application types. Thus, the three insecticide application types differed by: i) intensity of application, i.e. total amount of active ingredients applied per hectare and ii) amount of active ingredients applied per application per hectare. A higher effect (damage control) corresponded to a higher intensity, although such effect was achieved with lower value of the input-effect ratio, similarly to what is observed for the fungicide application types. The three types only slightly and not significantly differ with respect to the chemical class of insecticide applied (Table 6). 
Table 5. Fungicide application types.

\begin{tabular}{|c|c|c|c|c|c|c|c|c|c|}
\hline & \multirow[t]{2}{*}{ Units } & \multicolumn{3}{|c|}{$\begin{array}{l}\text { Least input- } \\
\text { effective ( } n=27)\end{array}$} & \multicolumn{3}{|c|}{$\begin{array}{l}\text { Middle input- } \\
\text { effective }(n=27)\end{array}$} & \multicolumn{2}{|c|}{$\begin{array}{l}\text { Most input- } \\
\text { effective }(n=26)\end{array}$} \\
\hline & & Mean & & SD & Mean & & SD & Mean & SD \\
\hline I-E index & - & 0.04 & $* * \star$ & -0.02 & 0.16 & $* * *$ & -0.05 & 0.38 & -0.09 \\
\hline Damage control (Exponential specification) & - & 1 & $* * *$ & -0.0001 & 0.9744 & *** & -0.0284 & 0.6814 & -0.1858 \\
\hline Intensity of application & kg a.i. / ha & 27.63 & $* * *$ & -15.3 & 7.13 & $* * *$ & -2.63 & 1.97 & -0.87 \\
\hline Number of applications & - & 9.7 & $* *$ & -3.33 & 5.89 & ** & -3.71 & 3.12 & -3.3 \\
\hline $\begin{array}{l}\text { Average intensity of application } \\
\text { Carbamates }\end{array}$ & $\begin{array}{c}\text { kg a.i. / } \\
\text { ha*application } \\
\text { kg a.i. / ha }\end{array}$ & $\begin{array}{r}1.71 \\
27.06\end{array}$ & ** & $\begin{array}{r}-0.84 \\
-15.31\end{array}$ & $\begin{array}{l}1.49 \\
6.88\end{array}$ & * & $\begin{array}{r}-1.9 \\
-2.72\end{array}$ & $\begin{array}{r}0.99 \\
1.8\end{array}$ & $\begin{array}{l}-0.99 \\
-0.88\end{array}$ \\
\hline $\begin{array}{l}\text { Share of carbamates on total quantity applied } \\
\text { Others }\end{array}$ & $\begin{array}{c}\% \\
\mathrm{~kg} \text { a.i. / ha }\end{array}$ & $\begin{array}{l}97.8 \\
1.52\end{array}$ & & $\begin{array}{l}-3.56 \\
-0.85\end{array}$ & $\begin{array}{r}96 \\
0.84\end{array}$ & & $\begin{array}{l}-8.05 \\
-0.61\end{array}$ & $\begin{array}{l}91.4 \\
0.43\end{array}$ & $\begin{array}{r}-16.51 \\
-0.48\end{array}$ \\
\hline Share of other fungicides on total quantity applied & $\%$ & 5.9 & & -3.4 & 13.61 & & -9.58 & 22.36 & -20.37 \\
\hline
\end{tabular}

Significant difference between application types (least vs. middle input-effective and middle vs. most input-effective): ${ }^{* * *} 1 \%,{ }^{* *} 5 \%,{ }^{*} 10 \%$ (Mann-Whitney test).

Table 6. Insecticide application types.

\begin{tabular}{|c|c|c|c|c|c|c|c|c|c|}
\hline & \multirow[t]{2}{*}{ Units } & \multicolumn{3}{|c|}{$\begin{array}{c}\text { Least input- } \\
\text { effective }(n=31)\end{array}$} & \multicolumn{3}{|c|}{$\begin{array}{l}\text { Middle input- } \\
\text { effective }(n=31)\end{array}$} & \multicolumn{2}{|c|}{$\begin{array}{c}\text { Most input- } \\
\text { effective }(n=31)\end{array}$} \\
\hline & & Mean & & SD & Mean & & SD & Mean & SD \\
\hline I-E index & - & 0.20 & $* * *$ & -0.09 & 0.55 & $* * *$ & -0.12 & 1.64 & -0.93 \\
\hline Damage control (Exponential specification) & - & 1.00 & $* * *$ & 0.00 & 1.00 & $* * *$ & 0.00 & 0.91 & -0.15 \\
\hline Intensity of application & kg a.i. / ha & 6.72 & $* * *$ & -4.48 & 1.90 & $* * *$ & -0.40 & 0.74 & -0.36 \\
\hline Number of applications & - & 8.35 & & -5.10 & 6.42 & ** & -3.98 & 4.23 & -2.85 \\
\hline Average intensity of application & $\begin{array}{c}\text { kg a.i. / } \\
\text { ha*application }\end{array}$ & 0.82 & $* * *$ & -1.02 & 0.35 & ** & -0.24 & 0.32 & -0.53 \\
\hline Organophosphates & kg a.i. / ha & 4.29 & $* * *$ & -3.59 & 0.79 & $* * *$ & -0.48 & 0.42 & -0.30 \\
\hline Share of organophosphates on total quantity applied & $\%$ & 56.54 & & -27.23 & 45.77 & & -29.92 & 63.71 & -30.90 \\
\hline Carbamates & kg a.i. / ha & 2.78 & $* * *$ & -2.31 & 1.24 & $* * *$ & -0.57 & 0.52 & -0.30 \\
\hline Share of carbamates on total quantity applied & $\%$ & 45.38 & & -26.00 & 62.39 & & -23.78 & 60.78 & -31.63 \\
\hline Pyrethroids & kg a.i. / ha & 1.21 & $* * *$ & -1.67 & 0.50 & $* * *$ & -0.45 & 0.18 & -0.13 \\
\hline Share of pyrethoids on total quantity applied & $\%$ & 19.54 & & -21.45 & 26.32 & & -24.42 & 26.83 & -23.35 \\
\hline
\end{tabular}

Share of pyrethoids on total quantity applied

$\%$

$19.54 \quad-21.45 \quad 26.32 \quad-24.42$

$26.83-23.35$

Significant difference between application types (least vs. middle input-effective and middle vs. most input-effective): *** $1 \%$, ${ }^{* *} 5 \%$, ${ }^{*} 10 \%$ (Mann-Whitney test). 


\subsubsection{Association of fungicide and pesticide application types}

The number of farmers adopting different combinations of fungicide and insecticide use types is shown in Table 7. Farmers tended to adopt fungicide and insecticide application types which were similar for input-effect ratio. The adoption of fungicide and insecticide use type is slightly but significantly correlated. If only farmers who reported use of pesticide are considered, the symmetric Somers' $d$ (ordinal measure of association) is 0.268 and significant at 0.01 level. If non-user farmers are also considered the Cramer's $V$ (nominal measure of association) is 0.232 and significant at 0.1 level.

The combination of the two types had also relevant consequences for the productivity achieved. Thus, farmers who adopted combinations of more intensive application types achieved higher productivity, which is consistent with the estimated production functions (Table 4), although their input-effect indexes tended to be lower (Table 7). That is, a trade-off existed between the maximisation of yield and input-effect ratio: farmers achieving high productivity were less input-effective in pesticide use, and vice versa. An exception to the correlation between application types and productivity was represented by farmers who reported no use of fungicide and adopted the least input-effective application type. However, the small number of these farmers hinders from drawing conclusions in this respect.

Table 7. Fungicide and insecticide application types matrix.

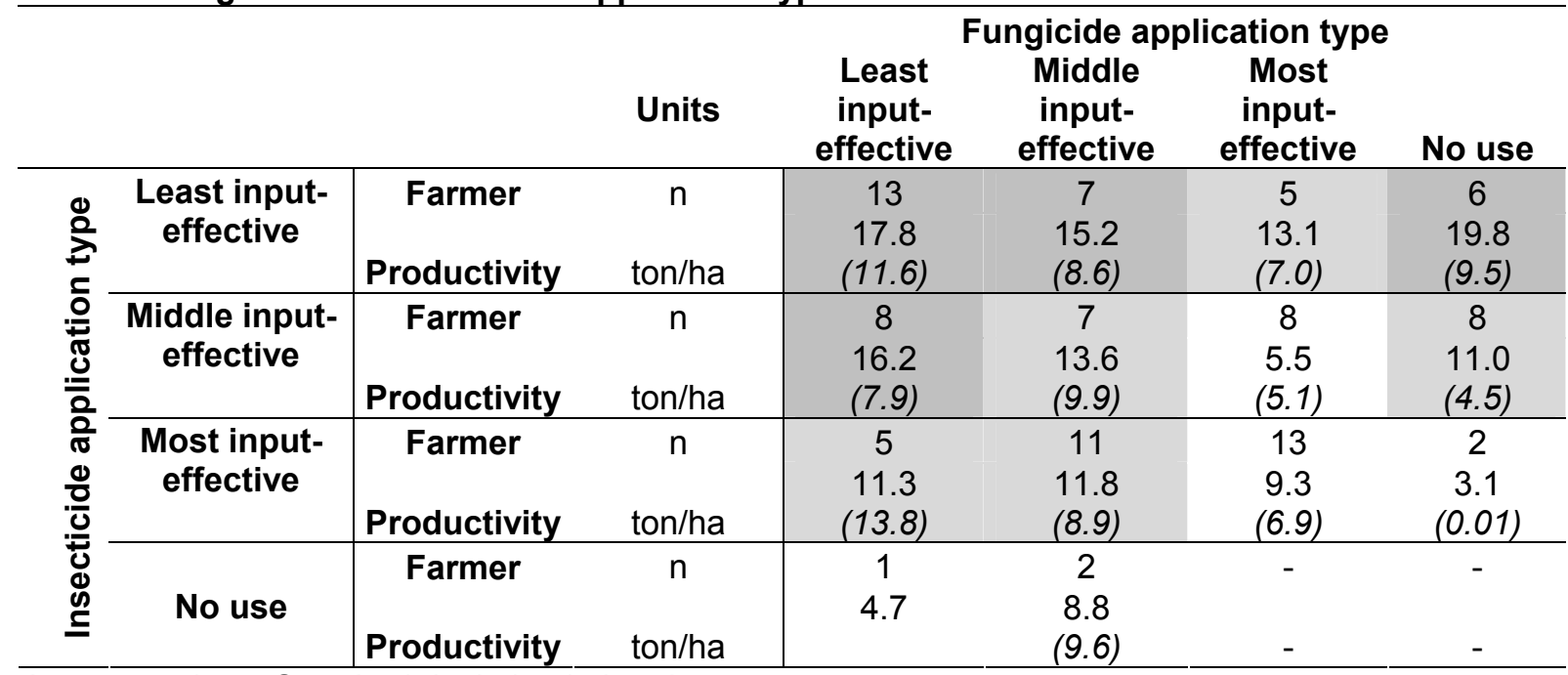

Average values. Standard deviation in brackets.

Legend: dark grey = above 15 tonnes per hectare (average productivity in the region; Ministerio de Agricultura y Desarrollo Rural, 2006); light grey = between 10 and 15 tonnes per hectare; white = below 10 tonnes per hectare (minimum satisfactory productivity; Baumberger, 2008)

\subsection{Determinants of adoption of different pesticide use types}

\subsubsection{The reduced models}

Maximum likelihood estimates of parameters in the multinomial logistic regression reduced models are presented in Tables 8 and 9 along with their significance level and the odds ratio $(\operatorname{Exp}(\beta))$, which is the factor by which the odds of adopting the least input-effective (lowest IE index), or the most input-effective (highest I-E index) application type instead of the middle input-effective one (middle I-E index) changes for a 1 unit change in the explanatory variable. For all the models, the Pearson $\mathrm{Chi}^{2}$ test is non-significant, meaning that the model has a good fit to the data. The adjusted Nagelkerke $R^{2}$, which ranges between 0.319 and 0.413 , indicates that the models have satisfactory explanatory power. 
Table 8. Estimates for fungicide application type.

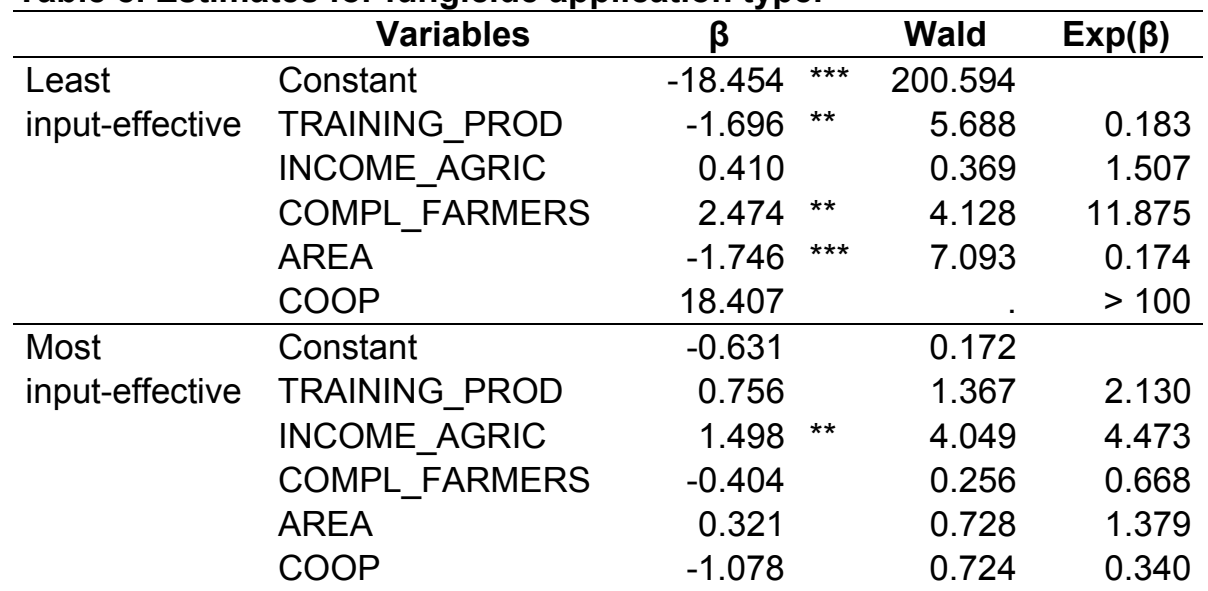

AIC: 135.076

$\mathrm{Chi}^{2}$ test of the model: $36.609^{* * *}$

Pearson test: 82.963

Nagelkerke $R^{2}: 0.413$

Significance: ${ }^{* *} 1 \%,{ }^{* *} 5 \%,{ }^{*} 10 \%$.

The reference category is "Middle input-effective".

All coefficients for dummy variable $=0$, except for continuous variables.

The adoption of different fungicide use types was significantly associated with the variables TRAINING_PROD, INCOME_AGRIC, COMPL_FARMERS and AREA. Farmers who received training from pesticide producing or selling companies were more likely to be less input-effective, which suggests that such training influenced farmers to apply fungicides intensively. Farmers whose income depended $75 \%$ or more on agriculture also tended to achieve a lower input-effect index. This may be explained by the fact that these farmers were heavily dependent on the crop and therefore more risk averse.

On the contrary, farmers with a high sense of compliance with the prescriptive norm were more likely to be more input-effective. In other words, when sharing information and trusting each other, farmers tended to achieve a higher input-effect index. In addition, farmers working larger parcels tended to achieve a higher input-effect index, which is in accordance with the estimates of the production function. Finally, as expected, belonging to a cooperative also strongly increased the probability of adopting the most input-effective application type ${ }^{5}$.

\footnotetext{
${ }^{5}$ The anomaly observed in Table 6 concerning the variable COOP is due to the small sample available for the study.
} 
Table 9. Estimates for insecticide application type.

\begin{tabular}{llrrr}
\hline & \multicolumn{1}{c}{ Variables } & $\boldsymbol{\beta}$ & Wald & Exp( $\boldsymbol{\beta})$ \\
\hline Least & Constant & -0.965 & 1.103 & \\
input-effective & EDUCATION & $0.356^{* *}$ & 5.673 & 1.427 \\
& TRAINING_PROD & $-0.7522^{*}$ & 1.664 & 0.471 \\
& EXTRA_INCOME & $1.401{ }^{* *}$ & 5.708 & 4.060 \\
& AREA & $-1.045^{*}$ & 3.635 & 0.352 \\
\hline Most & Constant & $-2.154^{* *}$ & 6.011 & \\
input-effective & EDUCATION & $0.271^{*}$ & 3.648 & 1.312 \\
& TRAINING_PROD & 0.804 & 2.059 & 2.236 \\
& EXTRA_INCOME & -0.153 & 0.073 & 0.858 \\
& AREA & 0.592 & 2.378 & 1.808 \\
\hline AIC: & & &
\end{tabular}

AIC: 183.419

$\mathrm{Chi}^{2}$ test of the model: $30.984 * * *$

Pearson test: 156.666

Nagelkerke R ${ }^{2}: 0.319$

Significance: ${ }^{* * *} 1 \%,{ }^{* *} 5 \%,{ }^{*} 10 \%$.

The reference category is "Middle input-effective".

All coefficients for dummy variable $=0$, except for continuous variables.

The adoption of different insecticide use types was significantly associated with the variables EDUCATION, EXTRA_INCOME and AREA. EDUCATION showed an unclear relation with the different types of insecticide use: more education increased the probability of a farmer to adopt in either the most or the least input-effective application type instead of the middle one. Farmers with an extra income not derived from agriculture tended to adopt most input-effective application type. Finally, similarly to what was found for fungicides, farmers who received training from pesticide producing or selling companies were more likely to adopt an intensive application type and farmers working larger parcels tended to achieve a higher input-effect index.

\subsubsection{Evidence from the full models}

Despite not providing fully reliable estimates, the full models added to the understanding of farmers' pesticide use. Table 10 shows the sign of the relationships as estimated in the full models for variables excluded from the reduced models, and only for the variables whose relationships showed a clear sign.

This feature suggests that farmers who received training from governmental agencies were more likely to achieve lower input-effect indexes in fungicide and insecticide use. Similarly, farmers who thought that other farmers were applying pesticide more intensively were more likely to adopt an intensive type, which suggests a tendency to conform to the descriptive norm (i.e. the belief about other farmers' behaviour). In addition, also cultivating the variety Ica Húila was associated with a negative influence on the input-effect index of pesticide use.

The sign of the estimates of the full model also suggests that AGE and LABELS were positively related to the input-effect index of insecticide use. That is, older farmers and farmers who read the labels on pesticide packages were more likely to adopt the middle or the most input-effective application type than the least input-effective one. On the other hand, LAHOYA and RESISTANCE were negatively associated with the efficiency of insecticide use. That is, farmers living in La Hoya and farmers perceiving growing pest resistance to chemicals were more likely to adopt an intensive application type, the latter suggesting an adaptive behaviour of the farmers to a changing environmental condition. 
Table 10. Sign of the relationships of the most relevant variables excluded in the reduced models.

\begin{tabular}{lcc}
\hline & \multicolumn{2}{c}{$\begin{array}{c}\text { Observed sign in the full } \\
\text { model }\end{array}$} \\
\multicolumn{1}{c}{ Variable } & Fungicides & Insecticides \\
\hline AGE & & + \\
LAHOYA & - & - \\
TRAINING & - & - \\
DESCR_NORM & - & - \\
LABELS & & + \\
RESISTANCE & - & - \\
VARIETY & - & - \\
\hline
\end{tabular}

\section{Discussion and conclusions}

The paper investigated pesticide use in four communities of smallholder potato producers in the Department of Boyacá, Colombia. The analysis showed that pesticide use positively and significantly contributed to productivity in the study area. Three application types were identified for fungicide and insecticide respectively, based on an input-effect index. The types differed in terms of input (intensity of pesticide application) and effect (damage control). As the analysis showed, the types also differed in terms of frequency of application, average quantity applied per application (only for fungicide), chemical class of the products applied, and productivity. Thus, the least input-effective application type for both fungicide and insecticide represented the most intensive type, which tended to be less varied in terms of chemicals applied, and which allowed higher damage control and productivity to be achieved, though at a lower input-effect ratio. On the contrary, the most input-effective application type for both fungicide and insecticide was characterised by higher levels of the input-effect index and variety of chemicals applied, but achieved on average a lower damage control and yield. The middle input-effective application type was for both fungicide and insecticide in between the two extremes. The combined analysis of fungicide and insecticide application types suggests that a trade-off existed between the maximisation of yield and input-effect ratio: farmers who achieved high productivity were less input-effective in pesticide use, and vice versa.

\subsection{Determinants of different pesticide application types}

The application of the IAC framework revealed the most relevant variables influencing farmers' pesticide use (Tables 8-10). Training provided by pesticide producers and sellers seemed to play a critical role in both fungicide and insecticide use, which confirms the key influence of private companies on smallholders observed in the same study area (Baumberger, 2008; Schoell and Binder, 2009), and in Latin America (Thrupp et al., 1995), and Cambodia, where pesticide sellers were considered to have a social status as high as that of "doctors" (EJF, 2001). Results suggest that such training was probably effective in increasing the productivity, but not input-effectiveness. Similarly, training provided by governmental agencies, which in the region consisted mainly of occasional workshops gathering small groups of farmers, seemed to influence the adoption of more intensive application types (Table 10), thus confirming the negative influence on productivity found in the production function (Table 4). In addition, the significant association between belonging to a cooperative and fungicide use might be explained by the fact that cooperatives targeted this issue more than insecticide use, probably organising training sessions (Oehler, 2008).

The area of the parcel was critical for the amount of both fungicides and insecticides applied, larger parcels allowing for better input-effectiveness. This might depend on the fact that the parcels cultivated by each farmer in the study area are usually far from each other, so that, for example, the leftover pesticide mix prepared for one parcel cannot be easily used in another one and is therefore applied in the same parcel even if not strictly necessary.

Income-related issues were also relevant for both fungicide and insecticide use, in concordance, for example, with the results of Rahman (2003) for Bangladesh. Dependence on the crop produced increased the probability of a farmer adopting the least input-effective 
application type, probably because farmers are more risk averse in this case. These farmers achieved a higher productivity, as shown in the results (Table 7), but also sustained proportionally higher crop protection costs than other farmers which adopted a type with a higher input-effect index.

Cultivating the variety Ica Húila, which was by far the most widely diffused in the study area, was also negatively associated with efficiency of both fungicide and insecticide use (Table 10), confirming that this variety is more vulnerable to pests than others, as stated by Moreno (2001). The farmers' frequent choice of this variety, which was more productive (Table 4) and also the most commonly used by the food processing industry in Colombia (Moreno, 2001), might indicate farmers' attempt to maximize production, but also the influence of market forces on smallholders in the region (Von Aesch, 2009).

Results suggest that farmers tended to conform to their beliefs about other farmers' behaviour (descriptive social norm) which confirms what Heong and Escalada (1999) and Heong et al. (2002) pointed out for insect management in Laos, and what Feola and Binder (2010) reported about the use of protective equipment in the same area. In effect, farmers who believed other farmers were applying pesticide intensively were likely to adopt themselves an intensive type (Table 10). Finally, results also suggest that farmers adapted to their perceived level of pest resistance to pesticides. This represents a further feedback process and, furthermore, points out the importance of farmers' knowledge of the agroecosystem and ability to detect this ecological process. However, due to the relatively small sample, it was not possible to fully quantify the effects of the two above mentioned feedbacks. Future work on farmers' pesticide use could further address these dynamics, understanding which seems particularly relevant for policy-relevant research, as the desired transition is likely to depend strongly on such adaptive change (Norgaard, 1984; Park and Seaton, 1996; Thompson et al., 2007).

\subsection{Policy implications: balancing productivity and input-effectiveness}

The combined analysis of fungicide and insecticide application types suggests that a tradeoff existed between productivity and input-effectiveness: farmers who achieved high productivity have lower input-effect index and vice versa. In addition, training programmes seemed to address yield maximisation more than pesticide use efficiency and farmers seemed to tend towards more intensive application types if their financial and technical resources allowed it. While maintaining high productivity rates is essential (Gobernación de Boyacá Dirección de Desarrollo Agropecuario, 2004), the present study shows that a better pesticide use could be fostered. A more input-effective application type would reduce pesticide intensity and consequently production costs and pesticide-related risks while maintaining what farmers consider a satisfactory productivity (Baumberger, 2008; see also Table 7). Some implications of the present study are outlined here, which may help the formulation of interventions in the region to target this issue.

Firstly, since it seems clear that the pesticide producing companies and the pesticide sellers play a crucial role in influencing farmers' crop protection choices, these actors should be involved if any change in pesticide application types are to be achieved. While many companies are worldwide promoting campaigns for a safe use of pesticide, there is evidence of little effectiveness of such intervention programs (e.g. Murray and Taylor, 2000). In particular, the analysis suggests that in the study area productivity maximization may be a much stronger priority both for trainers and farmers. Therefore, new strategies could be considered, which may also add to existing voluntary initiatives from pesticide producing companies, in order to make pesticide use more efficient and reduce potential adverse effects, and concomitantly achieve better productivity. The reduction of adverse effects would be further reduced by the substitution of highly toxic pesticides with less toxic ones. In effect, the formulations used in the study area mostly belong to toxicity classes I and II (Table 1), which suggests that a high potential exists for such substitution. This calls for an involvement of pesticide producers and sellers to facilitate the diffusion of less toxic pesticides, which might be combined with governmental regulations and system of incentives. Moreover, the implementation of training sessions held by governmental organizations may be reconsidered. For example, the gap could be filled, which exist between the divergent 
understandings of the agricultural system of farmers and extensionists, with consequent difficulties in communication and knowledge transfer, as showed for the study area by Schoell and Binder (2009).

Secondly, cooperatives seem to bring positive effects in terms of input-effectiveness in pesticide use, with the lower productivity being probably compensated by more stable contracts with buyers and a higher power on the market (both for inputs and yield). A support to local cooperatives could therefore result in a less intensive pesticide use.

Furthermore, by exploiting their higher power and a stronger network with other actors on the market, cooperatives may also acquire additional information, search for alternative markets and facilitate the adoption of different varieties of potato, therefore reducing the cultivation of the varieties which are more vulnerable to pests.

Thirdly, because farmers tend to conform to what they perceive to be the most common behaviour, i.e. application type, individual farmers are unlikely to change their behaviour alone. As pointed out by Feola and Binder (2010) with reference to the misuse of personal protective equipment in the same area of Boyacá, the presence of such social dynamics implies the need for intervening collectively instead of individually, also by e.g. promoting the social dialogue and participation on the topic, identifying active social networks and influential persons within them (Feola and Binder, 2010; see also Pretty, 1995).

These options for intervention call firstly, for a reconsideration of what kind of education is delivered to smallholders and, furthermore, suggest going beyond education programmes at all. As observed with regard to other cases in Latin America (Polidoro et al., 2008), also in the Department of Boyacá education might contribute, but it not be sufficient, to achieving more sustainable agricultural practices. Most farmers generally know pesticides risks, but are influenced by a vast array of structures in which unsafe or inefficient pesticide use may be the sensible or the only behavioural option possible (Murray and Taylor, 2000; Kishi, 2005). The present study confirms that the social context in which the farmer lives exert a fundamental influence on his crop protection decisions. While some factors such as the perception of pests' ability to resist to chemicals might be targeted by educational programs, other might require different intervention strategies. Thus, involving other agents of the agricultural system (i.e. pesticide producers and sellers), facilitating new institutional settings (i.e. cooperatives), and targeting social dynamics, in particular conformity to social norms, may increase the probability of successfully triggering a transition towards a more sustainable pesticide use.

\section{Acknowledgements}

The authors thank the farmers who participated in the survey, and are particularly grateful to Jaime Diaz, Tatiana Garcia and Gina Bautista of UniBoyacá for their essential support during the field phase and to Robert Finger and Christof Knoeri, for their comments on a previous version of this manuscript. The authors also thank Diana Diaz and Daniel Garcia of Corporación PBA and Eutimio Galán, who were fundamental in establishing contacts with local farmers and provided insightful views on the problems of smallholders in the region. Sincere thanks go also to Hans-Joachim Mosler and Robert Tobias for their comments on the earliest developments of this research. This research was funded by the Swiss National Science Foundation.

\section{References}

Akaike, H. 1973. Information Theory and an Extension of the Maximum Likelihood Principle. In: Petrou, N., Csadki, F. (Eds.), Proceedings of the 2nd International Symposium on Information Theory, Akademiai Kiado, Budapest.

Ashburner, J., Friedrich, T., 2001. Improving Handling of Pesticides Application Equipment for the Safety of Applicators. Pesticide Management in West Africa Newsletter no. 2. FAO/Economic Community of West African States, Accra, Ghana, pp. 9-11.

Atreya, K., 2007. Pesticide use knowledge and practice: A gender differences in Nepal'. Env. Res. 104, 305-310. 
Baumberger, N., 2008. Exposition, Überzeugungen und Risikoverhalten im Umgang mit Pestiziden: Eine Fallstudie bei Kartoffelnbauern in Vereda La Hoya, Kolumbien, Lizenziatsarbeit der Philosophischen Fakultät, University of Zurich.

Babcock, B.A., Lichtenberg, E., Zilberman, D., 1992. Impact of Damage Control and Quality of Output: Estimating Pest Control Effectiveness. Am. J. Agric. Econ. 74, 163-172.

Belcher, K.W., Boehm, M.M., Fulton, M.E., 2004. Agroecosystem sustainability: a system simulation modelling approach. Agric. Syst. 79, 225-241.

Berger, T., 2001. Agent-based spatial models applied to agriculture: a simulation tool for technology diffusion, resource use changes and policy analysis. Agric. Econ. 25, 245-260.

Binder, C.B., Patzel, N., 2001. Preserving tropical soil organic matter at watershed level. A possible contribution of urban organic wastes. Nutr. Cycl. Agroecosys. 61, 171-181.

Blackie, M., Gibbon, D., 2003. Enhancing impact. Strategies for the promotion of research technologies to smallholders in eastern and southern Africa. Report to the DFID Crop Protection Programme, Natural Resources International, Aylesford, UK.

Burleigh, J.R., Vingnanakulasingham, V., Lalith, W.R.B., Gonapinuwala, S., 1998. Type of pesticide use and pesticide efficacy among chili growers in the dry zone of NE Sri Lanka (System B): perception vs reality. Agric. Ecosyst. \& Env. 70, 49-60.

Carrasco-Tauber, C., Moffitt, L.J., 1992. Damage Control Econometrics: Functional Specification and Pesticide Productivity. Am. J. Agric. Econ. 74, 158-162.

Cowan, R., Gunby, P., 1996. Sprayed to Death: Path Dependence, Lock-in and Pest Control Strategies. The Econ. J. 106, 521-542.

Dent, J.B., Edwards-Jones, G., McGregor, M.J., 1995. Simulation of Ecological, Social and Economic Factors in Agricultural Systems. Agric. Syst. 49, 337-351.

Ecobichon, D. J., 2001. Pesticide use in developing countries. Toxicology 160, 27-33.

Edwards-Jones, G., 2006. Modelling farmer decision-making: concepts, progress and challenges. Anim. Sci. 82, 783-790.

EJF. 2001. 'Death in Small Doses: Cambodia's Pesticide problems and Solutions, Environmental Justice Foundation, London, UK.

Fedepapa and Ministerio de Ambiente, Vivienda y Desarrollo Territorial, 2004. Guía ambiental para el cultivo de la papa, Fedepapa and Ministerio de Ambiente, Vivienda y Desarrollo Territorial, Bogotá, Colombia.

Feola G., Binder R.C., 2009. The integrative agent-centred (IAC) framework as a conceptual tool to investigate transition processes in local agricultural systems'. Paper presented at the First European Conference on Sustainability Transitions: Dynamics and Governance of Transitions to Sustainability, June 4-6, Amsterdam, The Nederlands.

Feola G., Binder R.C. 2010. 'Why don't pesticide applicators protect themselves? Exploring the use of Personal Protective Equipment among Colombian smallholders. Int. J. Occup. Env. Heal. 16, 11-23.

Galt, R.E., 2008. Toward an Integrated Understanding of Pesticide Use Intensity in Costa Rican Vegetable Farming. Hum. Ecol. 36, 655-677.

Gobernación de Boyacá Dirección de Desarrollo Agropecuario, 2004. Acuerdo de competitividad de la cadena agroalimentaria de la papa, para el Departamento de Boyacá, Gobernación de Boyacá Dirección de Desarrollo Agropecuario, Tunja, Colombia.

Grossman, L.S., 1992. Pesticides, Caution, and Experimentation in St. Vincent, Eastern Caribbean. Hum. Ecol. 20(3), 315-336.

Heong, K.L., Escalada, M.M., 1999. Quantifying farmers' pest management decisions: beliefs and subjective norms in stem borer control. Crop Prot. 18, 315-322.

Heong, K.L.., Escalada, M.M., Sengsoulivong, V., Schiller, J., 2002. Insect management beliefs and practices of rice farmers in Laos. Agric. Ecosyst. \& Env. 92, 137-145.

Hosmer, D.W., Lemeshow, S., 2000. Applied logistic regression, Wiley, New York.

Kishi, M., 2005. The Health Impacts of Pesticides: What Do We Know?, in Pretty, J. (Ed.), Pesticide Detox, Earthscan, pp.23-38.

Leuenberger, M., 2005. Environmental and Health Risk Assessment of Cultivation Strategies in Tunjy, Colombia, Diploma Thesis Natural and Social Science Interface, ETH Zurich.

Lichtenberg, E. Zilberman, D., 1986. The Econometrics of Damage Control: Why Specification Matters. Am. J. Agric. Econ. 68, 261-273. 
Lin, B.H., Taylor, H., Delvo, H., Bull, L., 1995. Factors Influencing Herbicide Use in Corn Production in the North Central Region. Rev. Agric.I Econ. 17(2), 159-169.

Matthews, G.A., 2008. Attitudes and behaviours regarding the use of crop protection products - a survey of more than 8500 smallholders in 26 countries. Crop Prot. 27, 834846.

McGregor, M.J., M.F., Rola-Rubzen, Murray-Prior, R., 2001. Micro and macro-level approaches to modelling decision making. Agric. Syst. 69, 63-83.

Mekonnen, Y., Agonafir, T., 2002. Pesticides sprayers' knowledge, attitude and practice of pesticide use on agricultural farms of Ethiopia. Occup. Med.-Oxford 52, 311-315.

Ministerio de Agricultura y Desarrollo Rural, 2001. Acuerdo de competitividad de papa en el Departamento de Nariño, Ministerio de Agricultura y Desarrollo Rural, Bogotá, Colombia.

Ministerio de Agricultura y Desarrollo Rural, 2004. Costos de producción de papa en Colombia, Ministerio de Agricultura y Desarrollo Rural, Documento de trabajo No. 40, Bogotá, Colombia.

Ministerio de Agricultura y Desarrollo Rural, 2006. La cadena de la papa en Colombia. Una mirada global de su estructura y dinámica 1991-2005, Ministerio de Agricultura y Desarrollo Rural, Bogotá, Colombia.

Moreno, J., 2001. Variedades de papa que se siembran en Colombia, Working paper Programa Regional de Investigación Agrícola, Regional Uno, CORPOICA, Colombia.

Murray, D.L., Taylor, P.L., 2000. Claim No Easy Victories: Evaluating the Pesticide Industry's Global Safe Use Campaign. World Dev. 28(10), 1735-1749.

Norgaard, R. B., 1984. Coevolutionary Agricultural Development. Econ. Dev. Cult. Change 32, 525-546.

Oehler, J., 2008. The Influence of Farmer Organizations on The Sustainability of The Agricultural System in Less Developed Countries. An Assessment in the Department of Boyacá, Colombia, Diploma Thesis Department of Geography, University of Zurich.

Öhlmér, B., Olson, K., Brehmer, B., 1998. Understanding farmers' decision making processes and improving managerial assistance. Agric. Econ. 18, 273-290.

Oriade, C.A., Dillon, C.R., 1997. Developments in biophysical and bioeconomic simulation of agricultural systems: a review. Agric. Econ. 17, 45-58.

Ospina, J.M., Manrique, F.G., Ariza, N.E., 2008. Salud, ambiente y trabajo en poblaciones vulnerables: los cultivadores de papa en el centro de Boyacá, Revista de la Facultad Nacional de Salud Publica 26(2), 143-152.

Park, J., Seaton, R.A.F., 1996. Integrative Research and Sustainable Agriculture. Agric. Syst. 50, 81-100.

Polidoro, B.A., Dahlquist, R.M., Castillo, L.E., Morra, M.J., Somarriba, E., Bosque-Pérez, N.A., 2008. Pesticide application practices, pest knowledge and cost-benefits of plaintain production in the Bribri-Cabécar Indigenous Territories, Costa Rica. Env. Res. 108, 98-106.

Pretty, J.N., 1995. Participatory Learning for Sustainable Agriculture. World Dev. 23(8), 1247-1263.

Rahman, S., 2003. Farm-level pesticide use in Bangladesh: determinants and awareness. Agric. Ecosyst. \& Env. 95, 241-252.

Schoell, R., Binder, C.R., 2009. System Perspectives of Experts and Farmers Regarding the role of Livelihood Assets in Risk Perception: Results from the Structured Mental Model Approach. Risk Anal. 29(2), 205-222.

Thompson, J., Millstone, E., Scoones, I., Ely, A., Marshall, F., Shah, E., Stagl, S., 2007. Agrifood System Dynamics: pathways of sustainability in an era of uncertainty, STEPS Working Paper 4, Brighton: STEPS Centre.

Thomson PLM., 2006. Diccionario de especialidades agroquimicas', Thomson PLM, Bogotá, Colombia.

Thrupp, L.A., Bergeron, G., Waters, W.F., 1995. Bittersweet Harvests for Global Supermarkets: Challenges in Latin America's Agricultural Export Boom, World Resource Institute, Washington D.C, USA.

Tuchschmid, M., 2004. GIS-basierende räumliche Risikoabschätzung vom Pestizideinsatz in der Landwirtschaft. Fallstudie: Vereda La Hoya, Kolumbien. Master Thesis, Institute of Human Environment Systems, ETH Zurich. 
Von Aesch, I., 2009. Differences between Producer Prices in the Potato Market: An Economical Assessment in Tunja, Colombia, Master Thesis, Faculty of Business and Economics, University of Basel.

Webster, P., 1999. The Challenge of Sustainability at the Farm Level: Presidencial Address. J. Agric. Econ. 50(3), 371-387.

Williamson, S., Ball, A., Pretty, J., 2008. Trends in pesticide use and drivers for safer pesticide management in tour African Countries. Crop Prot. 27, 1327-1334.

Wilson, C., Tisdell, C., 2001. Why farmers continue to use pesticides despite environmental, health and sustainability costs. Ecol. Econ. 39, 449-462.

World Health Organzation (WHO), 1990. Public Health impact of pesticides used in agriculture, Geneva, Switzerland. 